\title{
Commentary: Myocardial regeneration with stem cells-Hope was never the problem!
}

\author{
Manan Desai, MD, Lok Sinha, MD, and Can Yerebakan, MD
}

\footnotetext{
From the Department of Cardiovascular Surgery, Children's National Heart Institute, The George Washington University School of Medicine and Health Sciences, Washington, DC.

Disclosures: Authors have nothing to disclose with regard to commercial support.

Received for publication July 9, 2019; revisions received July 20, 2019; accepted for publication July 25, 2019; available ahead of print Oct 4, 2019.

Address for reprints: Can Yerebakan, MD, Children's National Health System, The George Washington University School of Medicine and Health Sciences, 2300 I St NW, Washington, DC 20052 (E-mail: cyerebakan@ childrensnational.org).

J Thorac Cardiovasc Surg 2019;158:1624-5

$0022-5223 / \$ 36.00$

Copyright (C) 2019 Published by Elsevier Inc. on behalf of The American Association for Thoracic Surgery https://doi.org/10.1016/j.jtcvs.2019.07.071
}

In the last few decades, the discovery of the regenerative potential of the myocardium has led to experimental and clinical research efforts with significant resource utilization. ${ }^{1,2}$ Since the first administration of intracoronary and intramyocardial stem cells in adult ischemic heart disease, numerous attempts have followed with different sources and routes for cardiac stem cell therapy. ${ }^{3,4}$ While the safety of myocardial stem cells therapy was being confirmed in long-term clinical trials, their efficacy remained limited. ${ }^{5}$ The application of intramyocardial bone marrow stem cells in ischemic heart disease, however, has even reached phase III multicenter clinical trial stage in the adult patient population. ${ }^{6}$

Despite significant improvement in the surgical outcomes of congenital heart disease, the utilization of the regenerative potential of the young myocardium by current therapies is still insufficient. There is the need for supportive strategies, however, particularly in patients with singleventricle physiology undergoing 3-stage surgical palliation, for improved short- and long-term outcomes. One of the disastrous complications in patients with single-ventricle physiology is the failing systemic ventricle, ultimately leading to a Fontan failure and with few and limited therapeutic options. According to our current knowledge, myocardial regenerative strategies in the pediatric population ought to be applied early to derive the maximum potential. Cell therapies in patients with single-ventricle physiology were therefore already safely applied with cardiosphere-derived cells after single-ventricle palliation with limited but sustained effect on cardiac function. ${ }^{7,8}$ Autologous stem cells seem the most appropriate cell source to prevent an undesirable immune response by the host. Umbilical cord blood-derived mononuclear cells have been the focus of myocardial regeneration because of their pluripotent nature and the feasibility of autologous application. Previous research has shown beneficial angiogenetic, reverse remodeling, and functional effects of umbilical cord

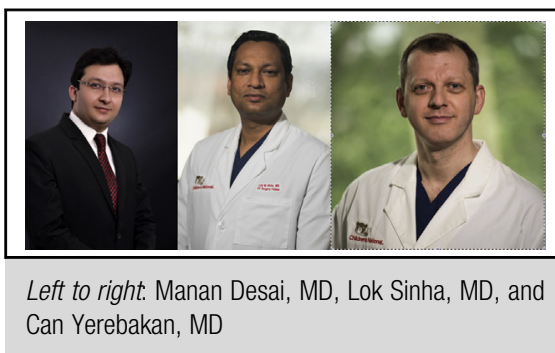

Central Message

Regenerative strategies bear the potential to become a sustained part of the surgical and medical management for congenital heart disease in the future.

See Article page 1614 .

blood-derived mononuclear cells in congenital heart surgery models in experimental protocols. ${ }^{9}$ The first clinical application followed a few years later. ${ }^{10}$

In this issue of the Journal, Burkhart and collaborators ${ }^{11}$ have published the results of a phase I trial reporting safety and feasibility of intramyocardial injection of the umbilical cord blood-derived mononuclear cells. Umbilical cord blood was collected at birth and processed for intramyocardial stem cell injection during the bidirectional Glenn operation, classic second-stage palliation for a single-ventricle pathway. The group are to be congratulated not only for their pioneering role in the stem cell treatment for congenital heart disease but also for the successful completion of this open-label phase I nonrandomized multicenter study despite its challenges in logistics and standardization of the treatment. Burkhart and collaborators ${ }^{11}$ aimed to prove safety and feasibility of their treatment strategy with right ventricular intramyocardial stem cell injections with 6 months of follow-up. Despite the limited number of treated patients, their current study shows an important step toward the implementation of standardized treatment protocols for regenerative stem cell strategies in congenital heart disease in phase II and III multicenter trials.

The interplay of paracrine effects of stem cells in their regenerative capability will be a pivotal area of interest. Latest research opens up the field for noncellular strategies to promote cardiac regeneration. Indeed, improvement in myocardial function after myocardial infarction was demonstrated after the injection of extracellular membrane vesicles containing microRNAs produced by cardiac 
progenitor cells into the peri-infarct zone. ${ }^{12}$ Similarly, extracellular vesicles derived from murine induced pluripotent stem cells demonstrated beneficial effects despite their noncellular nature in an experimental model with myocardial infarction. ${ }^{13}$

Within the last 4 decades, the improvement in the management of congenital heart disease has reflected the success of tremendous efforts in research and clinic. Similarly, successful translation of regenerative myocardial therapies into the clinical practice has the potential to boost the achievements beyond the capability of our already excelling surgical repair strategies. Future research on stem cell-based cardiac therapies will be challenged to answer a plethora of questions about stem cell treatment in congenital heart disease, such as cell types, noncellular stem cell-based strategies, timing, dosage and quality of the cell products, delivery routes, mode of stem cell effect, and cell tracking methods. We congratulate Burkhart and collaborators ${ }^{11}$ again for their important contribution.

\section{References}

1. Bergmann O, Bhardwaj RD, Bernard S, Zdunek S, Barnabé-Heider F, Walsh S, et al. Evidence for cardiomyocyte renewal in humans. Science. 2009;324:98-102.

2. Sanganalmath SK, Bolli R. Cell therapy for heart failure: a comprehensive overview of experimental and clinical studies, current challenges, and future directions. Circ Res. 2013;113:810-34.

3. Strauer BE, Brehm M, Zeus T, Gattermann N, Hernandez A, Sorg RV, et al. Intracoronary human autologous stem cell transplantation for myocardial regeneration following myocardial infarction. Dtsch Med Wochenschr. 2001;126:932-8. German.

4. Stamm C, Westphal B, Kleine HD, Gattermann N, Hernandez A, Sorg RV, et al. Autologous bone-marrow stem-cell transplantation for myocardial regeneration. Lancet. 2003;361:45-6.
5. Yerebakan C, Kaminski A, Westphal B, Donndorf P, Glass A, Liebold A, et al Impact of preoperative left ventricular function and time from infarction on the long-term benefits after intramyocardial $\mathrm{CD} 133^{+}$bone marrow stem cell transplant. J Thorac Cardiovasc Surg. 2011;142:1530-9.

6. Steinhoff G, Nesteruk J, Wolfien M, Kundt G, PERFECT Trial Investigators Group, Börgermann J, et al. Cardiac function improvement and bone marrow response-outcome analysis of the randomized PERFECT Phase III clinical trial of intramyocardial $\mathrm{CD}_{133^{+}}$application after myocardial infarction. EBioMedicine. 2017;22:208-24.

7. Tarui S, Ishigami S, Ousaka D, Kasahara S, Ohtsuki S, Sano S, et al. Transcoronary infusion of cardiac progenitor cells in hypoplastic left heart syndrome: three-year follow-up of the transcoronary infusion of cardiac progenitor cells in patients with single-ventricle physiology (TICAP) trial. J Thorac Cardiovasc Surg. 2015;150:1198-207, 1208.e1-2.

8. Ishigami S, Ohtsuki S, Eitoku T, Ousaka D, Kondo M, Kurita Y, et al. Intracoronary cardiac progenitor cells in single ventricle physiology: the PERSEUS (cardiac progenitor cell infusion to treat univentricular heart disease) randomized phase 2 trial. Circ Res. 2017;120:1162-73.

9. Yerebakan C, Sandica E, Prietz S, Klopsch C, Ugurlucan M, Kaminski A, et al. Autologous umbilical cord blood mononuclear cell transplantation preserves right ventricular function in a novel model of chronic right ventricular volume overload. Cell Transplant. 2009; 18:855-68.

10. Burkhart HM, Qureshi MY, Peral SC, O'Leary PW, Olson TM, Cetta F, et al; Wanek Program Clinical Pipeline Group. Regenerative therapy for hypoplastic lef heart syndrome: first report of intraoperative intramyocardial injection of autologous umbilical-cord blood-derived cells. J Thorac Cardiovasc Surg. 2015;149: e35-7.

11. Burkhart HM, Qureshi MY, Rossano JW, Cantero Peral S, O'Leary PW, Hathcock M, et al. Phase I results of autologous stem cell therapy for hypoplastic left heart syndrome: safety and feasibility of intraoperative intramyocardial injections. J Thorac Cardiovasc Surg. 2019;158:1614-23.

12. Agarwal U, George A, Bhutani S, Ghosh-Choudhary S, Maxwell JT, Brown ME, et al. Experimental, systems, and computational approaches to understanding the microRNA-mediated reparative potential of cardiac progenitor cell-derived exosomes from pediatric patients. Circ Res. 2017;120:701-12.

13. Adamiak M, Cheng G, Bobis-Wozowicz S, Zhao L, Kedracka-Krok S, Samanta A, et al. Induced pluripotent stem cell (iPSC)-derived extracellular vesicles are safer and more effective for cardiac repair than iPSCs. Circ Res. 2018 122:296-309. 